\title{
Study Literature: Traditional Game Based Learning Model Sitinjak to Find the Concept Area of Triangle
}

\author{
$1^{\text {st }}$ Dessy Rasihen \\ Graduate School of Mathematics Education \\ Yogyakarta State University \\ Yogyakarta \\ dessy.rasihen2016@student.uny.ac.id
}

\author{
$2^{\text {nd }}$ Jailani \\ Departement of Mathematics Education \\ Yogyakarta State University \\ Yogyakarta \\ jailani@uny.ac.id
}

\begin{abstract}
Diverse with technological sophistication and humans should keep abreast of technological developments, aspects of child development as the most important to support the success of learning are often overlooked. Such learning does not provide space for students to be able to learn according to the stage of development, given the development period that children love to play, love to move, happy to work in groups, and happy to do something directly. In addition, the teacher must also be able to create a fun learning, the student must be directly involved in the task or direct experience in learning. This is to achieve meaningful learning for students. This is in line with the opinion of the National Council of Teachers of Mathematics (2000), which explains that mathematics learning for middle-class students should involve them regularly in activities closely related to improving the ability to find and determine suspect structures and verify, hypothetical thinking, cause and effect, and abstraction and generalization. Based on this, a model of learning based on traditional games sitinjak was invented in discovering the broad concept of triangle. This learning model can help students in constructing their knowledge in finding the concept of triangle area. For this purpose, a study used a Research \& Development (R\&D) that uses the development model of Borg \& Gall by focusing on the product design stage. In this product design stage, a traditional game based learning model is designed to find the concept area of triangle was developed. The result of study is a traditional mathematics-based learning model wherein we find a broad concept of a triangle consisting of a syntactic, a social system, a reaction principle, a support system, and the impact of instructional and impact accompaniment.
\end{abstract}

Keywords-model of learning, based on traditional games, sitinjak, concept area of triangle.

\section{INTRODUCTION}

Mathematics as one of the basic science that has an important role in the mastery of science and technology. According to Erman Suherman, mathematics is one of the most important basic sciences taught to students so that (1) students have the ability to be converted through the use of mathematical activities; (2) students have math knowledge as preparation for continuing to secondary education; (3) students have math skills as an improvement and expansion of elementary school mathematics to be used in everyday life; (4) students have a fairly broad view and have a logical attitude, critical care, and discipline and appreciate the usefulness of mathematics [1].

Mathematics in junior high school is included in school mathematics. According to Ernest, "school mhatematics might prepare learners for the futher mathematical study, in wich case understanding, emmory, rapid use of subsidiary skills, development of mathematical thinking, ability to work with abstract concepts of increasing complexity might all be as important" meaning that school mathematics aims to prepare students for further learning. mathematics, in terms of understanding, memory, fast thinking, mathematical thought development, the ability to work with abstract concepts and increase complexity can all be seen as important. Based on the school mathematics objectives that Ernest has, school mathematics has an important role for students. Thus, teachers should be able to make learning mathematics fun and interesting, students should be directly involved in the task or experience directly in learning. This is for the achievement of meaningful learning.

In the process of learning mathematics as the learning process in general, students are expected to construct their own knowledge. This is supported by the opinion of Joyce, Weil \& Calboun who states that, "...the idea that learning is the construction of knowledge" [2]. The process of constructing knowledge by students can be influenced by several things, such as the stages in learning, the role of teachers, and the environment. These aspects are covered in terms called learning models.

The role of teachers during the learning process in the classroom is as a facilitator in constructing student knowledge during mathematics learning. Meanwhile, the environment becomes another source of student learning after the teacher. The environment is the beginning of the learning and thinking of each individual. Inside there are cultures and habits that 
are very familiar to each individual in the environment. Likewise with students and mathematics, the learning process will be more meaningful if mathematics can be presented in things that are close to student life such as culture and habits in the student environment.

Abdurrahman states, one of the uses of mathematics learning is a means to develop awareness of cultural development [3]. Culture is the result of human interaction with each other and their natural environment. Culture is defined as the whole system of thinking, values, morals, norms, and beliefs (beliefs) of human beings generated by society. Therefore, a person's math is influenced by his cultural setting because of what they do based on what they see and feel. Based on that, the culture is expected to be able to improve students' understanding of mathematics learning considering the usefulness of math learning itself.

One of the existing culture in Indonesia is the traditional game. Traditional game is a game created in the past where still looks familiarity among members of the community. Usually traditional games use simple tools that are easily obtained and are around the local community. This is in accordance with the opinion of Van den HeuvelPanhuizen who expresses the opinion of Freudenthal, "according to Frudenthal, mathematics must be connected to reality, stay close to children and be relevant to society in order to be of human value", which means that mathematics should be linked to the real world, staying close to the student and relevant to society [4].

Traditional games that exist in Indonesia one of them is sitinjak. Sitinjak is a traditional game from Riau province, Indonesia. Sitinjak is made of two logs or bamboo, each about 2 meters long. Then about $50 \mathrm{~cm}$ from the base of bamboo/ wood perforated then put bamboo with a size of $20-30 \mathrm{~cm}$ or wood that is nailed that serves as a footrest. This triangle-shaped footrest which will later become a learning tool in finding the concept of triangle.

The use of traditional games in this study is grounded in the opinion of Schultes \& Scannon who revealed that most students will increase their appreciation of mathematics after learning using a culture perspective that students have known [5]. In addition, the National Council of Teachings of Mathematics (2000), explains that junior high school students should often be involved in meaningful activities related to the ability to find structure, proof, hypothetical thinking, understand causality, abstraction and generalization [6]. This is because the essence of mathematics itself according to Ebbut and Straker is (1) as the activity of pattern and relationship search; (2) as creativity that requires imagination, intuition, and discovery; (3) as problem solving activities; (4) as a communication tool [7].
Based on the school mathematics above, we can know that mathematics not only conveys mathematical concepts, but rather is an activity to discover patterns, imagination, intuition and creativity. Mathematics learning in schools provides an opportunity for students to form a paradigm in understanding understanding as well as in reasoning relationships between mathematical meanings. This encourages teachers to select and use models, strategies, methods, approaches, and techniques that involve many students in learning activities.

Another thing that must be considered by teachers in determining the model of learning is to observe the characteristics of students. The junior age ranges from 12-14 years. In adolescence, students experience significant development in their lives, not only in physical changes, but also emotions and cognitions. In this case teachers are expected to support the success of student learning in schools through a process of significant development. This is reasoned because if the teacher has insight about the characteristics of students and able to support the success of student learning, then the teacher will be able to determine the type and characteristics of media that will be arranged including in determining the model of learning.

Based on the problem, the learning model is in line with the characteristics of junior high school students and involves the students' experience in their learning process using the traditional game of Sitinjak which is integrated into the learning to find the concept of area triangle. This learning model can be an alternative teacher in applying the concept of area triangle in grade VII students of junior high school.

\section{LITERATURE REVIEW}

\section{A. Learning Model}

Good teaching is a teaching that embraces the infinite learning experience of how both (teachers and students) can change according to an atmosphere that also changes [8]. Gunter, Estes \& Schwab, stated "an instructional model is a step-by-step procedure that leads to specific learning outcomes" [9]. The purpose of the statement is the learning model is a procedure that leads to specific learning objectives.

Further Joyce, Weil, \& Calhoun stated, "a model of teaching is a description of learning environment, including our behavior as teachers when that models are used" [10]. The opinion defines that a learning model is a description of the learning environment, including our behavior as teachers when the learning model is used. Another opinion about the definition of the learning model is delivered by Sa'dun Akbar who says that, the learning model is the pattern in designing the learning, or the learning step and its tools to achieve the learning objectives [11]. Related to that, Joyce, Weil, with Shower stated that, a 
learning model can be analyzed in accordance with the four core operational concepts of model that characterize: (1) syntactic, (2) social system, (3) reaction principle, (4) support systems, and (5) instructional and supportive impacts [12].

Based on the expert's opinion, the authors conclude that the learning model is a pattern, plan or description of a learning environment that is formed with the help of systematic procedures (regular) in organizing activities (experience) learning that serves as a guide for teachers in planning and carrying out learning activities in the classroom achieve learning objectives (learning competencies) in creating effective and efficient learning in accordance with the objectives of learning.

\section{B. Component Learning Model}

Learning model has several components that are used in finding the concept of area of triangle, that is:

1. Has a syntactic

Syntax is a sequence / phase of activity or learning steps. The steps of learning activities in this study can be specifically presented in study plan or Rencana Pelaksanaan Pembelajaran (RPP) which consists of introduction, core activities and cover.

2. There is a social system

Social system here in the form of situations or atmosphere and norms that apply in the model. The social systems contained in the traditional game-based mathematics learning model are as follows (1) active students in active learning and teachers to become learning facilitators; (2) students can solve problems either individually or in groups; and (3) teachers encourage conducive interaction and negotiation in student group activities

3. There is a reaction principle

The principle of reaction here is an activity pattern that describes how teachers should see and treat students, including how teachers should respond to them. This principle provides guidance on how teachers should use established game rules.

\section{Have a support system}

The support system in this learning model is all the tools, materials, and tools necessary to implement the traditional game-based mathematics learning model. The means used in this learning model in the form of Student Worksheet or Lembar Kerja Siswa (LKS) and a matter of understanding test.

5. Have the impact of instructional and impact accompaniment

Instructional impact related to the achievement of basic competencies that can be implemented through the test of student learning outcomes. Impact accompaniment of other results generated by a learning process, as a result of the creation of learning atmosphere experienced directly by students without direct direction from the teacher [13]. Impact accompanist in the development of traditional math-based learning model of this game in the form of increased appreciation of students in learning.

\section{Traditional Games Sitinjak}

Traditional games come from traditional and word games. The game means something or stuff that is used to play, while the traditional is behavior, way of thinking, and doing something that is always based on existing norms and habits from generation to generation. Traditional games have great value for future generations in order to create, imagine, and media to practice community life [14].

Traditional games have existed for a long time in community groups from Indonesian ancestors. Traditional games use tools that are inexpensive, easy to reach, simple, and not technology-based. Children today are not familiar with traditional games. Children are more interested in playing gadgets or modern games that use sophisticated equipment. According to Nur, the reality that is happening today is the activity of children's play today switch to modern games that use technology tools such as video games and online games [15]. This should be a homework together because the traditional games are not lost and forgotten by Indonesians, especially children.

Traditional games that exist in Indonesia many varieties, each region has its own traditional game. One of the traditional Indonesian games sitinjak. Sitinjak is a traditional game originating from Riau province, Indonesia. traditional games sitinjak can be found in various regions with different names such as: parts of West Sumatra with the name of the Tengkak-tengkak from the word Tengkak (lame), Ingkau which in Bengkulu means bamboo shoes and in Central Java with the name Jangkungan derived from the name long-legged birds, and enggrang in the language of Lampung, which means spindles made of long bamboo beads. whereas, in Banjar in South Kalimantan it is called batungkau.

Sitinjak is made of two logs or bamboo, each about 2 meters long. Then about $50 \mathrm{~cm}$ from the base of bamboo / wood perforated then put bamboo with a size of $20-30 \mathrm{~cm}$ or wood that is nailed that serves as a footrest. The winner in this game is determined by the player who first gets to the finish line. 


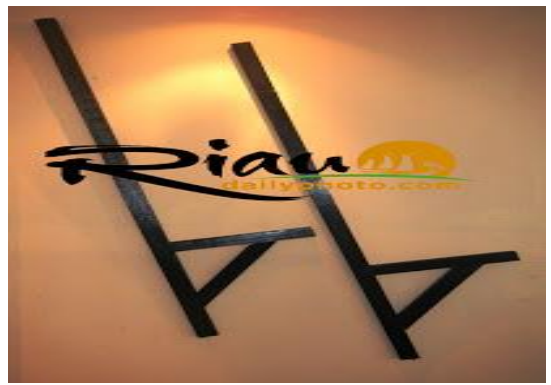

Fig. 1. Permainan Tradisional Sitinjak

Teachers who have an important role in learning can insert traditional games into the learning of mathematics. Such games can be utilized to construct learners' knowledge of concepts or formulas in mathematics. In this case the game sitinjak utilized to find the concept of the area of triangle. By gaining direct experience through such traditional games, learners will more easily understand the concepts that are being studied and the heritage culture of ancestors hereditary can still be preserved.

The use of traditional games sitinjak in learning needs to be accompanied by class discussions to discuss and develop informal mathematical knowledge gained from traditional games into formal and abstract mathematical concepts. The cooperation formed in the game can train student collaboration and interaction. Ariyadi Wijaya said that the game can be an effective tool for improving learning and understanding of learning topics. One example of such benefits is how the games of Indonesian children (i.e. bets and marbles) can support long-term learning processes [16].

Keep in mind, the selection of traditional games that will be used by teachers in learning mathematics in school, make sure already know this game first, both from how to play until the rules of the game, so that the expected learning objectives are achieved and learning takes place as expected. Based on this, traditional game sitinjak expected to improve students' understanding the area of triangle considering the usefulness of learning mathematics it self.

\section{METHOD}

The study used a Research \& Development (R\&D) that used the development model of Borg \& Gall by focusing on the product design stage [17]. In product design stage, design of traditional game based-learning model sitinjak to find the concept area of triangle called draft I. The result of study is a model of learning mathematics based on traditional game sitinjak in finding the concept of area of triangle consisting of a syntactic, a social system, a reaction principle, a support system, and the impact of instructional and impact accompaniment.

\section{RESULT AND DISCUSSION}

The result of study is syntax of traditional game based-learning model sitinjak to find the concept area of triangle. The learning steps (syntax) of the learning model are presented in the Lesson Plans or Rencana Pelaksanaan Pembelajaran (RPP). As for the traditional game-based model of defense defenders sitinjak in find the concept area of triangle, among others:

1. The first stage, set the concept, namely:

a. Clarify learning objectives

b. Determine the traditional game that can be used in finding the area of the triangle

c. Arranging the concept

2. The second stage, making the work of the traditional game activities that exist in the LKS, namely:

a. Preparation of work results in a LKS

b. Teacher's guidance, and

c. Revision

3. The third stage, presentation of the work of the traditional game activities in the LKS

4. The fourth stage, reflection and evaluation

a. Conclude together about the truth and accuracy of the work that has been made

b. Evaluation by providing self-help exercises (PR)

Below is presented traditional game game basedlearning model sitinjak to find the concept area of triangle presented in the Lesson Plans or Rencana Pelaksanaan Pembelajaran (RPP) :

TABLE I. THE SYNTAX OF TRADITIONAL GAMEBASED LEARNING MODEL SITINJAK TO FIND THE CONCEPT AREA OF TRIANGLE

\begin{tabular}{|c|c|c|c|}
\hline \multicolumn{3}{|c|}{ Activity Description } & \multirow{2}{*}{$\begin{array}{c}\text { Time } \\
\text { Allocation }\end{array}$} \\
\hline Activities & Teachers Activities & Teachers Activities & \\
\hline \multicolumn{4}{|c|}{ The First Stage (Setting the Concept) } \\
\hline \multirow{3}{*}{ Introduction } & $\begin{array}{l}\text { 1. The teacher } \\
\text { opens the process } \\
\text { of learning by } \\
\text { saying hello, and } \\
\text { the teacher asks } \\
\text { one of the } \\
\text { students to lead } \\
\text { the prayer }\end{array}$ & $\begin{array}{l}\text { 1. Students } \\
\text { answer } \\
\text { teacher's } \\
\text { greetings and } \\
\text { pray led by } \\
\text { one of the } \\
\text { students } \\
\text { Respond } \\
\text { teacher's } \\
\text { greetings and } \\
\text { prayers led by } \\
\text { class leader }\end{array}$ & \\
\hline & $\begin{array}{l}\text { 2. The teacher } \\
\text { checks for } \\
\text { student } \\
\text { attendance }\end{array}$ & $\begin{array}{l}\text { 2. Students } \\
\text { respond by } \\
\text { saying } \\
\text { "Present" or } \\
\text { show up when } \\
\text { hand teachers } \\
\text { do attendance }\end{array}$ & \\
\hline & $\begin{array}{l}\text { 3. Teachers explain } \\
\text { the learning } \\
\text { objectives to be } \\
\text { achieved that is to } \\
\text { find / mentate the } \\
\text { circumference } \\
\text { formula and the } \\
\text { area of the }\end{array}$ & $\begin{array}{l}\text { 3. Students listen } \\
\text { to the learning } \\
\text { objectives to be } \\
\text { achieved }\end{array}$ & \\
\hline
\end{tabular}




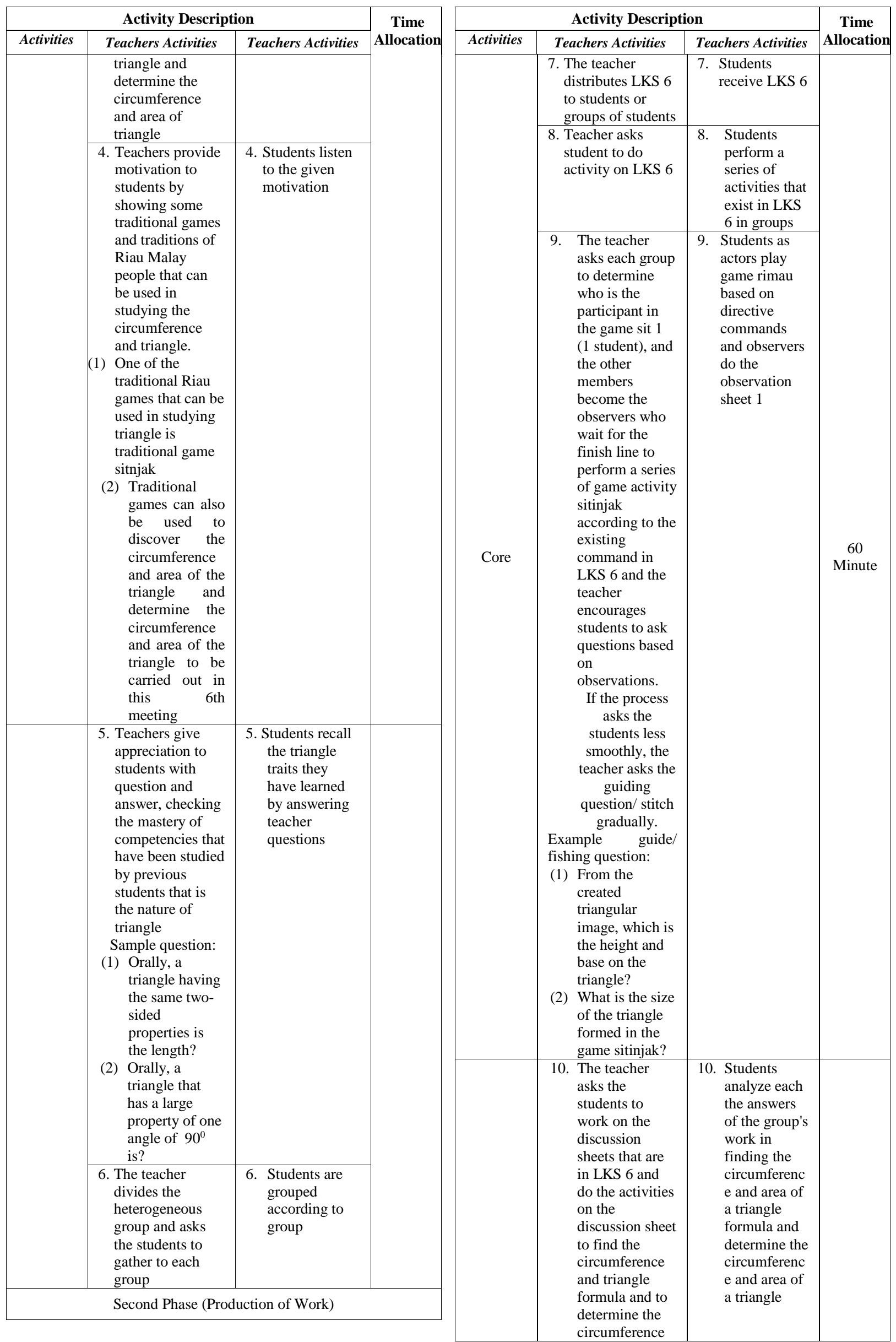




\begin{tabular}{|c|c|c|c|}
\hline \multicolumn{3}{|c|}{ Activity Description } & \multirow{2}{*}{$\begin{array}{c}\text { Time } \\
\text { Allocation }\end{array}$} \\
\hline Activities & Teachers Activities & Teachers Activities & \\
\hline & and triangle & & \\
\hline & $\begin{array}{l}\text { 11. The teacher } \\
\text { monitors and } \\
\text { helps the } \\
\text { troubled group } \\
\text { by asking a few } \\
\text { questions: } \\
\text { (1) Have you done } \\
\text { everything } \\
\text { right? } \\
\text { (2) Are there any } \\
\text { difficulties you } \\
\text { meet? If yes on } \\
\text { which part of } \\
\text { the difficulty? } \\
\text { (3) How did you } \\
\text { overcome these } \\
\text { problems? }\end{array}$ & $\begin{array}{l}\text { 11. Students } \\
\text { analyze each } \\
\text { results of } \\
\text { answers of } \\
\text { his group } \\
\text { work in } \\
\text { finding / } \\
\text { mentioning } \\
\text { the } \\
\text { circumferenc } \\
\text { e formula } \\
\text { and the area } \\
\text { of triangle } \\
\text { and } \\
\text { determining } \\
\text { the } \\
\text { circumferenc } \\
\text { e and area of } \\
\text { triangle of a } \\
\text { series of } \\
\text { aktfitas that } \\
\text { have been } \\
\text { done }\end{array}$ & \\
\hline \multicolumn{4}{|c|}{ Third Stage (Work Presentation) } \\
\hline & $\begin{array}{l}\text { 12. The teacher } \\
\text { summoned one } \\
\text { of the groups to } \\
\text { report the } \\
\text { results of his } \\
\text { group } \\
\text { discussion in } \\
\text { front of his } \\
\text { friend. }\end{array}$ & $\begin{array}{l}\text { 12. Students } \\
\text { explain and } \\
\text { explain the } \\
\text { results of the } \\
\text { discussion in } \\
\text { front of } \\
\text { friends and } \\
\text { other groups }\end{array}$ & \\
\hline & $\begin{array}{l}\text { 13. Teachers } \\
\text { provide } \\
\text { opportunities } \\
\text { for students } \\
\text { from other } \\
\text { groups to } \\
\text { respond to the } \\
\text { group } \\
\text { presenting their } \\
\text { discussion }\end{array}$ & $\begin{array}{l}\text { 13. Students } \\
\text { from other } \\
\text { groups } \\
\text { responded to } \\
\text { the group } \\
\text { presenting } \\
\text { the results of } \\
\text { their } \\
\text { discussion }\end{array}$ & \\
\hline & $\begin{array}{l}\text { 14. The teacher } \\
\text { distributes } \\
\text { rewards to the } \\
\text { group } \\
\text { presenting the } \\
\text { results of the } \\
\text { discussion in } \\
\text { front of his or } \\
\text { her friends and } \\
\text { to students from } \\
\text { other groups } \\
\text { who respond }\end{array}$ & $\begin{array}{l}\text { 14. The student } \\
\text { receives a } \\
\text { reward from } \\
\text { the teacher } \\
\text { for the results } \\
\text { of his or her } \\
\text { group's } \\
\text { discussion or } \\
\text { response }\end{array}$ & \\
\hline & $\begin{array}{l}\text { 15. The teacher } \\
\text { asks the } \\
\text { students to do } \\
\text { self-training } \\
\text { questions as a } \\
\text { comprehension } \\
\text { test on LKS } 6\end{array}$ & $\begin{array}{l}\text { 15. Students } \\
\text { work on self- } \\
\text { training } \\
\text { questions on } \\
\text { LKS } 6 \text { from } \\
\text { teachers }\end{array}$ & \\
\hline \multicolumn{4}{|c|}{ Phase Four (Reflection and Evaluation) } \\
\hline Cover & $\begin{array}{l}\text { 16. The teacher } \\
\text { guides the } \\
\text { students to } \\
\text { reflect on their } \\
\text { learning } \\
\text { activities on this }\end{array}$ & $\begin{array}{l}\text { 16. Students } \\
\text { reflect on } \\
\text { today's } \\
\text { learning } \\
\text { activities } \\
\text { together that }\end{array}$ & $\begin{array}{c}15 \\
\text { Minute }\end{array}$ \\
\hline
\end{tabular}

\begin{tabular}{|c|c|c|c|}
\hline \multicolumn{3}{|c|}{ Activity Description } & \multirow{2}{*}{$\begin{array}{c}\text { Time } \\
\text { Allocation }\end{array}$} \\
\hline Activities & Teachers Activities & Teachers Activities & \\
\hline & $\begin{array}{l}\text { day: finding / } \\
\text { mentioning the } \\
\text { circumference } \\
\text { \& triangular } \\
\text { formula and } \\
\text { determining the } \\
\text { circumference } \\
\text { and area of the } \\
\text { triangle, by } \\
\text { luring the } \\
\text { students through } \\
\text { several } \\
\text { questions: } \\
\text { (1) What have you } \\
\text { learned today? } \\
\text { (2) What do you } \\
\text { understand } \\
\text { from today's } \\
\text { mathematics } \\
\text { learning } \\
\text { materials? } \\
\text { (3) What have you } \\
\text { not understood } \\
\text { from today's } \\
\text { math learning? } \\
\text { What is the } \\
\text { reason. }\end{array}$ & $\begin{array}{l}\text { is reviewing } \\
\text { what has } \\
\text { been learned }\end{array}$ & \\
\hline & $\begin{array}{l}\text { 17. Teachers } \\
\text { provide } \\
\text { homework or } \\
\text { Pekerjaan } \\
\text { Rumah to } \\
\text { improve } \\
\text { students' } \\
\text { understanding } \\
\end{array}$ & $\begin{array}{l}\text { 17. Students } \\
\text { receive } \\
\text { homework or } \\
\text { Pekerjaan } \\
\text { Rumah (PR) }\end{array}$ & \\
\hline & $\begin{array}{l}\text { 18. The teacher } \\
\text { presents the } \\
\text { material to be } \\
\text { learned at the } \\
\text { next meeting, to } \\
\text { study at home is } \\
\text { to estimate the } \\
\text { irregular wake } \\
\text { area }\end{array}$ & $\begin{array}{l}\text { 18. Students } \\
\text { listen and } \\
\text { write the next } \\
\text { learning }\end{array}$ & \\
\hline & $\begin{array}{l}\text { 19. The teacher } \\
\text { asks one of the } \\
\text { students to pray } \\
\text { to close the } \\
\text { lesson }\end{array}$ & $\begin{array}{l}\text { 19. One student } \\
\text { leads a } \\
\text { prayer to } \\
\text { close } \\
\text { learning } \\
\end{array}$ & \\
\hline
\end{tabular}

\section{CONCLUSION AND SUGGESTION}

Traditional game based learning model sitinjak to find the area of triangle concept is expected to be an alternative, innovation and support the success of student learning and provide learning experiences so that learning becomes meaningful. Thus, teachers are expected to create a fun learning for students and attention to the characteristics of students to create a learning mathematics fun, effective, and efficient for students themselves. The selection of traditional game types should still be considered and adapted to the material to be studied. 


\section{REFERENCES}

[1] Suherman, E. Evaluasi Pembelajaran Matematika. Bandung: JICA UPI, 2001.

[2] Joyce, B., Weil, M., \& Calhoun, E. Models of Teaching ( $7^{\text {th }}$ ed). Boston: Allyn \& Bacon, 2004.

[3] Abdurrahman, Mulyono. Anak Berkesulitan Belajar: Teori, Diagnosis, dan Remediasinya. Jakarta: Rineka Cipta, 2012.

[4] Van den Hauvel, P.M. Assesment and realistic mathematics education. Utrecht: Freudenthal Institute, 1996.

[5] Schultes, \& Shannon. Comparison of the final grades of students in intermediate algebra taught with and without an etnomathematical Pedagogy. Diambil pada tanggal 11 Juli 2017, from http://www.rpi.edu/ eglash/isgem.di, 2001.

[6] NCTM, Principle and Standards for School Mathematics, Reston: Viginia, 2000.

[7] Ebbutt, S and Straker, A. Children and Mathematics: A Handbook for Teacher. London: Collins Educational.

[8] Joyce, B., Weil, M., \& Calhoun, E. Models of Teaching (7 $7^{\text {th }}$ ed). Boston: Allyn \& Bacon, 2004.

[9] Gunter, M. A., Estes, T. H., \& Schwab, J. H. Instruction: A models approach. Boston: Allyn and Bacon, 1990.
[10] Joyce, B., Weil, M., \& Calhoun, E. Model of Theacing (model-model pengajaran $8^{\text {th }}$ ed. Yogyakarta: Pustaka Pelajar, 2004.

[11] Sa'dun, Akbar. Instrumen Perangkat Pembelajaran. Bandung : Remaja Rosdakarya, 2013.

[12] Joyce, B., Weil, M., \& Calhoun, E. Model of Theacing (model-model pengajaran $8^{\text {th }}$ ed. Yogyakarta: Pustaka Pelajar, 2009.

[13] Udin S. Winataputra, dkk. Materi dan Pembelajaran MatemtaikaSD. Jakarta: Universitas Terbuka, 2008.

[14] Andriani, T. Permainan Tradisional dalam Membentuk Karakter Anak Usia Dini. Jurnal Sosial Budaya, vol. 9(1), pp. 121-136, 2012.

[15] Nur, H. Membangun Karakter Anak Melalui Permainan Anak Tradisional. Jurnal Pendidikan Karakter, vol. 3(1), pp. 87-94, 2013.

[16] Ariyadi, Wijaya. Manfaat Permainan Tradisional untuk PMRI. Yogyakarta: Makalah Seminar PMRI di Universitas Sanata Dharma tanggal 28 April 2009.

[17] Borg. W.R. dan Gall, M.D. Educational Research: An Introduction. New York: Longman, 1983. 